\title{
A prospective study about functional and anatomic consequences of transanal endoscopic microsurgery
}

\author{
J. A. Gracia Solanas, J. M. Ramírez Rodríguez, V. Aguilella Diago, M. Elía Guedea and M. Martínez Díez \\ Section of Coloproctology. Department of Surgery 'B'. Hospital Clínico Universitario. Zaragoza, Spain
}

\begin{abstract}
Introduction: transanal endoscopic microsurgey (TEM) was developed in 1983 by Büess as a minimally invasive technique to manage rectal villous adenomas and early rectal adenocarcinomas. Many studies have been published worldwide about its excellent results in morbidity and recidive rate, but there are few studies addressing functional results. The objective of this study is to analyze the effect of this technique in the anal anatomy and compare with the manometric results.

Material and methods: we devised a prospective study of 40 patients. 39\% female, $61 \%$ male. All of them filled an incontinence questionnaire (Pescatori scale) and endoanal ultrasonography and manometry was carried out preoperatively, third month postoperative and at sixth month only if incontinence appeared.

Results: 32 patients (80\%) had villous adenomas and 8 patients $(20 \%)$ had adenocarcinomas (uT1). Three patients complained of flatus incontinence at $3^{\text {rd }}$ postoperative month that disappeared with normal continence at $6^{\text {th }}$ month. Anorectal manometric values: mean anal resting pressure (ARP) decreased at $3^{\text {rd }}$ month (from $87.2 \mathrm{mmHg}$ to $70.1 \mathrm{mmHg}$ ), as it was for maximal squeeze pressure (MSP) from $152.5 \mathrm{mmHg}$ preoperatively to $142.2 \mathrm{mmHg}$ at $3^{\text {rd }}$ month. Ultrasonography demonstrated internal anal sphincter (IAS) rupture in 3 patients, with a full integrity of the external anal sphincter in all patients.

Conclusions: during TEM, a significant anal dilatation occurs, because of rectoscopy ( $40 \mathrm{~mm}$ wide), what can produce a rupture of IAS, with the consequent decreasing in ARP, and a dilatation without rupture of external sphincter what produces a decreasing of MSP. The fall of anal pressures had minima clinical repercussion when sphincter is intact, but when IAS is broken a temporal incontinence develops.
\end{abstract}

Key words: Faecal incontinence. Transanal endoscopic microsurgery. Anal manometry. Endoanal ultrasonography.

Recibido: 15-04-05.

Aceptado: 22-09-05.

Correspondencia: José Antonio Gracia Solanas. C/ Miguel Servet, 43, $6^{\circ}-$ $1^{\mathrm{a}}$, escl. izda. 50013 Zaragoza. e-mail: josegraciasolanas@ hotmail.com
Gracia Solanas JA, Ramírez Rodríguez JM, Aguilella Diago V, Elía Guedea M, Martínez Díez M. A prospective study about functional and anatomic consequences of transanal endoscopic microsurgery. Rev Esp Enferm Dig 2006; 98: 234-240.

\section{INTRODUCTION}

Transanal endoscopic microsurgery (TEM) was developed in 1983 by G. Büess (1) for local management of villous adenomas and early rectal carcinoma of the rectum $(2,3)$.

From the anal canal sphincter, the internal muscle (IAS) produces a continuous tonic contraction and the external anal sphincter (EAS), which surrounds IAS, originates an additional contraction in selected moments. To evaluate both, anal manometry measures mean anal resting pressure (ARP) that gives an idea of the IAS and after a voluntary contraction maximal squeeze pressure (MSP) can be measured to evaluate EAS.

TEM is performed by a $20 \mathrm{~cm}$ long rectoscope which allows to introduce up to four instruments through its $4 \mathrm{~cm}$ wide tube. This rectoscope is introduced in rectum after a gently anal dilatation. Its position is usually changed during operation, what combined with a large operation time, can be traduced in IAS damage risk that decreases anal resting pressure, and in a distension without rupture of EAS that decreases maximal squeeze pressure (4-7).

Many studies have been published worldwide about its good results in morbidity $(2,8,9)$, mortality, recurrence, and cost (10) when this technique is compared with classical surgical approaches.

However few reports in the literature look through functional results after surgery and we have not been able to find any in Spain. 
The objective of this study is to analyze the effect of this technique on the anal anatomy, comparing it with the manometric results.

\section{MATERIAL AND METHODS}

We devised a prospective descriptive study of 40 consecutive patients who underwent transanal endoscopic microsurgery in the Department of Surgery "B" of Hospital Clínico of Saragossa according to the technique designed by Büess $(1,11,12)$.

We included 40 patients in this study: 32 patients $(80 \%)$ underwent surgery because of villous adenomas y 8 patients $(20 \%)$ because of uT1N0 adenocarcinomas. Mean age of these patients was $67 \pm(10)$ year-old. Twenty four $(60 \%)$ were men and $16(40 \%)$ were women.

Every patient, who underwent TEM, was preoperatively staged with fibrocolonoscopy, rigid rectoscopy, and endorectal ultrasonography (13). To carry on this study each patient had to fill in a continence questionnaire that is shown in table I (Pescatori score) (14). Anorectal manometry data, anal resting pressure, maximal squeeze pressure, and rectoanal inhibitory reflex were recorded. Endoanal ultrasonography studied the integrity and thickness of IAS and EAS. Controls were planned at third postoperative month, and, when incontinence was present, at sixth postoperative month.

Table I. Pescatori continence score

\begin{tabular}{ll}
\hline Losses & Frequency \\
\hline A: flatus/mucus incontinence & $1:$ occasional \\
B: liquid stool incontinence & $2:$ weekly \\
C: solid stool incontinence & $3:$ daily \\
\hline
\end{tabular}

Scale: 0: continence; 6: severe incontinence (C3).

The inclusion criteria for this study were adenomas and uT1N0 adenocarcinomas located up to $20 \mathrm{~cm}$ from the anal verge.

The exclusion criteria were: previously anal surgery, preoperative defects of IAS revealed by ultrasonography or preoperative incontinence noticed by Pescatori' score.

Results were analyzed for statistical significance $(\mathrm{p}<$ $0,05)$ using $U$ de Mann-Whitney-Wilcoxon test. For this purpose we used Statview 5.0.1 software and we calculated mean, standard derivation and range.

\section{RESULTS}

The operating time was of $93 \pm 53 \mathrm{~min}$ (range 20-270 min). Tumour major size was $3.34 \pm 1.7 \mathrm{~cm}$. As a mean, the distance from the anal verge to the inferior margin of the tumour was $7.57 \pm 4.8 \mathrm{~cm}$ and to the upper margin was
$11.34 \pm 4.8 \mathrm{~cm}$. Full thickness excision was performed in $85 \%$ of patients and mucosectomy in $15 \%$ of them. Eighty percent of tumors were villous adenomas and the remaining 20\% were pT1N0 adenocarcinomas. Morbidity: 4 patients $(10 \%)$ had self-limited rectal bleeding in immediately postoperative, without hemodynamic consequences and none required either blood transfusion or reoperation.

Four patients preoperatively complained of urgent defecation, but only 2 of them still had this symptom at $3^{\text {rd }}$ postoperative month.

The results of continence questionnaire (Pescatori' score) (7) are: first control after surgery, 6 patients (15\%) had incontinence to flatus that disappeared at $6^{\text {th }}$ postoperative month (Table II). Four of these patients had IAS rupture with a decrease of ARP. The other two patients although did not had IAS rupture, had preoperatively a low ARP, and after operation both complained of anal leakage, what produced flatus losses.

Table II. Pescatori' score results

\begin{tabular}{lccc}
\hline & Preoperative & $\begin{array}{c}3^{\text {rd }} m \text { after } \\
\text { surgery }\end{array}$ & $\begin{array}{c}6^{\text {th }} m \text { after } \\
\text { surgery }\end{array}$ \\
\hline$N^{0}$ patients & 40 & 40 & 40 \\
Mucus/flatus incontinence & - & 6 & - \\
Liquid stool incontinence & - & - & - \\
Solid stool incontinence & - & - & - \\
Daily & - & 4 & - \\
Weekly & - & 2 & - \\
Occasional & - & - & - \\
\hline
\end{tabular}

IAS thickness fell from $2.1 \pm 0.8 \mathrm{~mm}$ preoperative value to $1.8 \pm 0.4 \mathrm{~mm}$ at first control, demonstrated by endoanal ultrasonography. In 6 patients an IAS rupture was confirmed (Table III) that produced gas incontinence; four of them were full continent at $6^{\text {th }}$ postoperative month. The other two patients with IAS rupture did not have an ARP decrease so they had normal continence.

The number of stools per day decreased from $1.8 \pm 1.5$ before surgery to $1.6 \pm 0.9$ at $3^{\text {rd }}$ month $(p>0.05)$.

Table III. Endoanal ultrasonography results

\begin{tabular}{lcc}
\hline & Preoperative & $3^{\text {rd }}$ m postoperative \\
\hline Integrity IAS $(\mathrm{n})$ & $40(100 \%)$ & $34(85 \%)$ \\
Thickness IAS & $2.1 \pm 0.8 \mathrm{~mm}$ & $1.8 \pm 0.4 \mathrm{~mm}$ \\
Integrity EAS $(\mathrm{n})$ & $40(100 \%)$ & $40(100 \%)$ \\
Thickness EAS & $4 \pm 0.7 \mathrm{~mm}$ & $3.9 \pm 0.9 \mathrm{~mm}$ \\
\hline
\end{tabular}

IAS: internal anal sphincter; EAS: external anal sphincter.

We observed a global fall both APR $(\mathrm{p}<0.001)$ and MSP $(p<0.05)$ after surgery. When we divided patients between continent and incontinent we did not find statistical significance (Table IV). We noticed inhibitory rectal 
Table IV. Anorectal manometry results

\begin{tabular}{lcc}
\hline & Preoperative & $3^{\text {rd }}$ m postoperative \\
\hline ARP $(\mathrm{mmHg})$ & $87.2 \pm 25.2$ & $70.1 \pm 31.4^{*}$ \\
-Continent $(\mathrm{n}=34)$ & $88.4 \pm 23.2$ & $71.3 \pm 27.2$ \\
-Incontinent $(\mathrm{n}=6)$ & $80.4 \pm 18.4$ & $63.3 \pm 24$ \\
\hline MSP $(\mathrm{mmHH})$ & $152.5 \pm 45.2$ & $142.2 \pm 51.1^{* *}$ \\
-Continent $(\mathrm{n}=34)$ & $154 \pm 45$ & $145 \pm 52$ \\
-Incontinent $(\mathrm{n}=6)$ & $144 \pm 37$ & $127 \pm 36$ \\
\hline RIR $(\%)$ & $100 \%$ & 32 patients $(80 \%)$ \\
\hline
\end{tabular}

$* p<0.001 ; * * p<0.05$

ARP: anal resting pressure; MSP: maximal squeeze pressure; RIR: rectoanal inhibitory reflex. No patient complained of incontinence at $6^{\text {th }}$ month so manometry was not repeated.

anal reflex extinction in $20 \%$ of our patients $(8 / 40)$ what can be explained by the surgical technique performed, that was a full thickness excision in all of them.

In comparing incontinent and continent patients (tumour diameter, location, operation time and surgical technique) no statistical significance was found (Table V).

Table V. Continent/incontinent patient comparison

\begin{tabular}{lcc}
\hline & $\begin{array}{c}\text { Continent pat. } \\
(n=34)\end{array}$ & $\begin{array}{c}\text { Incontinent pat. } \\
(n=6)\end{array}$ \\
\hline Location: & & \\
$\quad$ Posterior & 13 pat. $(38 \%)$ & 3 pat. \\
$\quad$ Anterior & 7 pat. $(20 \%)$ & 1 pat. \\
$\quad$ Lateral & 14 pat. $(41 \%)$ & 2 pat. \\
Tumor diameter $(\mathrm{cm})$ & $3.28 \pm 1.7$ & $3.93 \pm 2.15$ \\
Operation time $(\mathrm{min})$ & $92.01 \pm 50.5$ & $96.2 \pm 35.5$ \\
Surgery technique performed: & & \\
$\quad$ Mucosectomy & 6 & 1 \\
$\quad$ Full thickness excision & 28 & 5 \\
\hline p values $>0.05$. & &
\end{tabular}

\section{DISCUSSION}

The best results of local excision of rectal tumours when we compare with classical "open" techniques is worldwide demonstrated, with less morbidity $(2,8,9)$ and less recidive rate in adenomas and early adenocarcinomas (pT1). Its results in advanced stages with curative intention are still questioned until protocolized studies arrive. Few papers about functional consequences of TEM have been published.

In our study, both APR and MSP decreased at third postoperative month, what reveals a sphincterian apparatus injury produced by surgery.

The anal pressures fall due to anal dilatation is well known because of anal separators and stapling instruments used in coloproctological procedures for hemorrhoids, fistula, or cancer (15-17).
The integrity of both EAS and IAS, would explain that patient were continents although ARP decreased. The rupture of IAS in 6 patients, demonstrated by endoanal ultrasonography, produced some degree of incontinence in 4 of them.

The mean action of EAS is to delay urgent defecation, so 2 of 4 patients that preoperatively had urgent defecation, it can be ascribed to tumor because EAS was intact as demonstrated by ultrasonography.

Rectal inhibitory anal reflex (RIR) is a reflex within rectal wall that disappears when rectal wall is removed, as it happens in low anterior resections (18). We noticed in manometry the extinction of RIR in $20 \%$ of our patients $(8 / 40)$, that can be explained due to the surgical technique (in all of them a full thickness excision was employed).

Similar results are offered by other authors, showing that incontinence after transanal microsurgery is mild and time limited (4-6).

Although this is a non-randomised study, with low evidence, we found that anal pressures descent during the early postoperative is a major risk of incontinence when an injured IAS is associated. However this incontinence is transitory, because all of our patients were continent at $6^{\text {th }}$ month after surgery.

The comparison of our results after TEM with other continence studies after low anterior resection (19-21) is a difficult task, but normal continence at six postoperative month after TEM help us to maintain that functional results are good and probably better than classical 'open' approaches with higher incontinence rates.

We have to point out that this study was done in patients without previous anal injuries and normal continence. We have noticed mean anal pressures fall and internal anal sphincter ruptures so we have to keep our mind on patients who have or can develop any degree of sphincterian mechanism weakness.

\section{ACKNOWLEDGEMENT}

This study has been partially done thanks to financial support of "Fondo de Investigación Sanitaria del Ministerio de Sanidad y Consumo", Spain (Proyecto FIS 95/1136, Proyecto FIS 98/0788 and Proyecto FIS 01/0186).

\section{REFERENCES}

1. Büess G, Hutterer F, Theis J, Böbel M, Isselhard W, et al. Das System Für die transanale Endoskopische Rektumoperatio. Chirurg 1984; 55: 677-80.

2. Mentges B, Buess G, Effinger G, Manncke K, Becker HD. Indications and results of local treatment of rectal cancer. Br J Surg 1997; 84 (3): 348-51.

3. Lee W, Lee D, Choi S, Chun H. Transanal endoscopic microsurgery and radical surgery for T1 and T2 rectal cancer. Surg Endosc 2003 17 (8): $1283-7$ 
4. Herman RM, Richter P, Walega P, Popiela T. Anorectal sphincter function and rectal barostat study in patients following transanal endoscopic microsurgery. Int J Colorectal Dis 2001; 16 (6): 370-6.

5. Kennedy ML, Lubowski DZ, King DW. Transanal endoscopic microsurgery excision: is anorectal function compromised? Dis Colon Rectum 2002; 45 (5): 601-4.

6. Kreis ME, Jehle EC, Haug V, Manncke K, Bues GF, Becker HD, et al. Functional results after transanal endoscopic microsurgery. Dis Colon Rectum 1996; 39 (10): 1116-21.

7. Endreseth BH, Wibe A, Svinsas M, Marvik R, Myrvold HE. Postoperative morbidity and recurrence after local excision of rectal adenomas and rectal cancer by transanal endoscopic microsurgery. Colorectal Dis 2005; 7 (2): 133-7.

8. Steele GD, Herndon JE, Bleday R, Russell A, Benson A, Hussain M, et al. Sphincter-sparing treatment for distal rectal adenocarcinoma. Ann Surg Oncol 1999; 6 (5): 413-5.

9. Mellgren A, Sirivongs P, Rothenberger DA, Madoff RD, GarciaAguilar J. Is local excision adequate therapy for early rectal cancer? Dis Colon Rectum 2000; 43 (8): 1064-71.

10. Cocilovo C, Smith LE, Stahl T, Douglas J. Transanal endoscopic excision of rectal adenomas. Surg Endosc 2003; 17 (9): 1461-3.

11. Arribas D, Ramírez JM, Aguilella V, Elia M, Palacios MJ, Martínez M. Cirugía endoscópica transanal en los tumores de recto. Rev Esp Enferm Dig 2000; 92 (8): 526-30.

12. Ramírez JM, Aguilella V, Arribas D, Martínez M. Transanal Endoscopic Microsurgery should the defect be sutured? A randomised an controlled trial. Colorectal Disease 2002; 4: 51-5.
13. Ramírez Rodríguez JM, Mortensen NJMcM, Smilgin-Humphreys MM. La endoecografía anal en el estudio de la incontinencia fecal. Rev Esp Enferm Dig 1995; 87 (3): 211-5.

14. Pescatori M, Anastasio G, Bottini C, Mentasti A. A new grading and scoring for anal incontinence. Evaluation of 335 patients. Dis Colon Rectum 1992; 35 (5): 482-7.

15. MacDonald A, Smith A, McNeil AD, Finlay IG. Manual dilatation of the anus. Br J Surg 1992; 79: 1381-2.

16. Horgan PG, O'Conell PR, Shinkwin CA, Kirwan WO. Effect of anterior resection on anal sphincter function. Br J Surg 1989; 76: 783-6.

17. Yik-Hong HO, Tsang C, Tang CL, Nyam D, Eu KW. Anal sphincter injuries from stapling instrument introduced transanally. Dis Colon Rectum 2000, 43 (2): 169-73.

18. Pedersen IK, Hint K, Olsen J, Christiansen J, Jensen P, Mortensen PE. Anorectal function after low anterior resection for carcinoma. Ann Surg 1986; 204: 133-5.

19. Van Duijvendijk P, Slors JF, Taat CW, van Tets WF, van Tienhoven $\mathrm{G}$, Obertop H, et al. Prospective evaluation of anorectal function after total mesorectal excision for rectal carcinoma with or without preopeartive radiothearpy. Am J Gastroenterol 2002; 97 (9): 2282-9.

20. Jehle EC, Haehnel T, Starlinger J, Becker HD. Level of the anastomosis does not influence functional outcome after anterior rectal resection for rectal cancer. AM J Surg 1995; 160: 147-53.

21. Williamson ME, Lewis WG, Finan PJ, Miller AS, Holdsworth PJ, Johnston D. Recovery of physiologic and clinical function after low anterior resection of the rectum for carcinomas: myth or reality? Dis Colon Rectum 1995; 38: 411-8. 